\title{
Leaf Colour Chart vis-a-vis Nitrogen Management in Different Rice Genotypes
}

\author{
Avijit Sen, Vinod Kumar Srivastava, Manoj Kumar Singh, Ram Kumar Singh, Suneel Kumar \\ Department of Agronomy, Institute of Agricultural Sciences, Banaras Hindu University, Varanasi, India. \\ Email: avijitbhu@hotmail.com \\ Received February $16^{\text {th }}, 2011$; revised April $25^{\text {th }}$, accepted May $1^{\text {st }}, 2011$.
}

\begin{abstract}
A field trial comprising 3 rice varieties (NDR-359, Sarju 52, HUBR 2-1) and 4 LCC scores $(\leq 2, \leq 3, \leq 4, \leq 5)$ along with the recommended dose of $N$ was conducted in a split plot design to calibrate the LCC for nitrogen requirement of rice. Maximum grain yields of NDR-359, Sarju 52 at LCC $\leq 5$ and HUBR 2-1 at LCC $\leq 4$ were found to be 47.10, 40.66 and 36.04 q/ha respectively. The critical LCC score for real time nitrogen requirement for NDR 359 and Sarju 52 was found to be $\leq 5$, while for HUBR 2-1 it was $\leq 4$. Agronomic and recovery efficiency of nitrogen also followed the same trend. In the functional relationship between SPAD value and LCC score, while it was linear in NDR-359 and Sarju 52, for HUBR 2-1 it was quadratic. Further a positive correlation between SPAD values and LCC score was observed in all the 3 varieties.
\end{abstract}

Keywords: Leaf Colour Chart (LCC), Nitrogen, Rice

\section{Introduction}

Rice is the most important source of staple food in India occupying 44.6 Mha of land and producing 91.04 Mt of grain with a productivity of $2.04 \mathrm{t} / \mathrm{ha}$ [1]. Every third person on the earth eats rice everyday in one form or the other and $90 \%$ of the total rice produced is consumed in Asian countries. However, India's productivity is very low in comparison to other major rice growing countries in the world. Among various reasons for this low productivity, inefficient utilization of nitrogen in considered to be the most critical one [2]. On the recent world-wide evaluation of fertilizer, its recovery efficiency has been found to be around $30 \%$ in rice [3]. It has been observed that more than $60 \%$ of applied nitrogen is lost due to lack of synchronization between the nitrogen demand and nitrogen supply [4]. Farmers generally apply nitrogen fertilizer in fixed time recommended $\mathrm{N}$ split schedule [5] in 1:2:1 or $2: 1: 1$ ratio at basal, maximum tillering and panicle initiation stages respectively, without taking into account whether the plant really requires $\mathrm{N}$ at that time which may lead to loss or may not be found adequate enough to synchronize nitrogen supply with actual crop nitrogen demand [6].

The optimum use of $\mathrm{N}$ can be achieved by matching $\mathrm{N}$ supply with crop demand [7]. A simple and quick method for estimating plant $\mathrm{N}$ demand is LCC i.e. leaf colour chart [8] and SPAD (chlorophyll meter) readings which can estimate leaf chlorophyll content in a nondestructive manner [9], thereby providing an indirect assessment of leaf N status [10]. LCC is easy to use and is an inexpensive diagnostic tool for monitoring the relative greenness of a rice leaf as an indicator for the plant $\mathrm{N}$ status and can be used as an alternative to chlorophyll meter [11]. It offers substantial opportunities to farmers for detection of time and amount of $\mathrm{N}$ to be applied (on demand) for efficient $\mathrm{N}$ use and high rice yield. Thus LCC becomes useful in avoiding under or above fertilization besides maintaining the appropriate time [12]. Use of LCC for $\mathrm{N}$ management has consistently increased grain yield and profit in comparison to the farmers' fertilizer practice in Bangladesh [13-15]. However, critical LCC values vary considerably among different rice genotypes having different genetic background, plant type and leaf colour [16] and this critical colour shade on the LCC needs to be determined to guide $\mathrm{N}$ application [7]. Keeping this in view the following field trial was conducted to determine the critical threshold LCC values for different rice genotypes on the basis of growth, yield, agronomic and recovery efficiency of $\mathrm{N}$.

\section{Materials and Methods}

A field trial was conducted during the two consecutive 
kharif (rainy) seasons of 2005 and 2006 in the Agricultural Research Farm of the Institute at Varanasi $\left(25^{\circ} 18^{\prime} \mathrm{N}\right.$ latitude, $88^{\circ} 3^{\prime} \mathrm{E}$ longitude and at an altitude of $128.90 \mathrm{~m}$ above mean sea level) situated in the Indo-Gangetic plain regions of the eastern part of Uttar Pradesh. The climate of Varanasi is semiarid subtropical with dry hot summer and cold winter. The average annual rainfall is $1150 \mathrm{~mm}$, major part of which is received during the later part of June to mid September. The soil of the experimental site was sandy clay loam in texture, deep flat, slightly alkaline in reaction $(\mathrm{pH} 7.3)$, well drained and moderately fertile being low in available nitrogen $(208.00 \mathrm{~kg} / \mathrm{ha})$ and phosphate $(15.20 \mathrm{~kg} / \mathrm{ha})$ and medium in available potassium $(231.40 \mathrm{~kg} / \mathrm{ha})$. The organic carbon content was $0.43 \%$ (Table 1).

The experiment was laid out in a split plot design with four replications. Three rice genotypes, NDR 359 (a medium duration high yielding variety released from NDUAT, Faizabad with a yield potential of $4-5 \mathrm{t} / \mathrm{ha}$ ), Sarju 52 (a 130 - 135 days duration variety having a yield potential of $5.0-5.5 \mathrm{t} / \mathrm{ha}$ with long, bold grain) and HUBR 2-1 (an aromatic rice genotype of 135 - 140 days duration with relatively thinner leaf developed and released by Banaras Hindu University with an average yield of $4.0-4.5 \mathrm{t} / \mathrm{ha}$ ) were grown in the main plots while the five fertilizer $\mathrm{N}$ (as urea) management treatments were allotted to sub-plots. In all the varieties the LCC scores of $\leq 2, \leq 3, \leq 4$ and $\leq 5$ were compared with fixed time recommended $\mathrm{N}$ rate of $120 \mathrm{~kg} / \mathrm{ha}$. In the recommended $\mathrm{N}$ rate treatment, nitrogen was applied in 1:2:1 ratio at the time of sowing, maximum tillering and panicle initiation stages respectively. A uniform dose of phosphorous and potassium @ 60 kg/ha each and Zn@ 5 $\mathrm{kg} / \mathrm{ha}$ were applied to all the plots as basal.

\subsection{Crop Raising}

The experimental field was prepared by puddling twice with disc harrow and one with cultivator and each ploughing was followed by planking. After preparing the field 30 days old seedlings were transplanted on $5^{\text {th }} \mathrm{July}$, 2005 and $10^{\text {th }}$ July 2006 at a spacing of $20 \times 15 \mathrm{~cm} @$ $3 / 4$ seedlings/hill. After the establishment of seedlings a constant water level of $5 \pm 2 \mathrm{~cm}$ was maintained during the entire crop growth period till early dough stage. For the management of weeds two hand weeding were done at 25 and 45 days after transplanting (DAT) respectively. The crop was harvested manually at maturity at ground level on $12^{\text {th }}$ October, 2005 and $14^{\text {th }}$ October, 2006 respectively. Grain (at 13\% moisture content) and straw yield on sun dry weight basis were reported in $\mathrm{q} / \mathrm{ha}$.

\subsection{Leaf Colour Chart}

The LCC developed by the Directorate of Rice Research, Hyderabad, India with seven green shades ranging from yellowish green to dark green was used in the trial. LCC readings were taken at 4 days interval starting from 10 DAT till 50\% flowering. 10 disease free hills were selected at random from the sampling area in each plot. From each hill topmost fully expanded leaf was selected and LCC readings were taken by placing the middle part of the leaf on the chart and the leaf colour was observed by keeping the sun blocked by body as sun light affects leaf colour reading. Whenever the green colour of more than 5 out of 10 leaves were observed equal to or below a set critical limit of LCC score, nitrogen was applied @ $20 \mathrm{~kg} / \mathrm{ha}$ to all the three varieties. For all the varieties the final split application of $\mathrm{N}$ was completed by $61 / 62$ days after transplanting coinciding with the heading stage. A basal application of $30 \mathrm{~kg} / \mathrm{N}$ ha was made in all the cases as per prevalent package of practices of this area (Table 2). The SPAD reading of the same leaf used for LCC measurement was also taken at three stages on 30,60 and 90 DAT. The chlorophyll meter (SPAD - 502, Minolta, Ramsey, NJ) or SPAD (Soil Plant Analysis Development)

Table 1. Physical and chemical properties of soil of the experimental site.

\begin{tabular}{|c|c|c|}
\hline \multirow{2}{*}{ Parameters } & \multicolumn{2}{|c|}{ Soil Particular Value } \\
\hline & 2005 & 2006 \\
\hline \multicolumn{3}{|l|}{ Physical } \\
\hline Bulk density $\left(\mathrm{g} \cdot \mathrm{cc}^{-1}\right)$ & 1.46 & 1.48 \\
\hline True density $\left(\mathrm{g} \cdot \mathrm{cc}^{-1}\right)$ & 2.63 & 2.65 \\
\hline Pore space $(\%)$ & 45.50 & 44.50 \\
\hline WHC (cm) & 35.71 & 34.84 \\
\hline Sand $(\%)$ & 48.84 & 49.10 \\
\hline Clay $(\%)$ & 22.41 & 22.29 \\
\hline Texture & Sandy Clay Loam & Sandy Clay Loam \\
\hline \multicolumn{3}{|l|}{ Chemical } \\
\hline $\mathrm{pH}(1: 2.5$ soil water suspension $)$ & 7.32 & 7.30 \\
\hline EC ( $1: 2.5$ soil water suspension) & 0.14 & 0.15 \\
\hline Organic carbon $(\%)$ & 0.42 & 0.43 \\
\hline Available $\mathrm{N}\left(\mathrm{kg} \cdot \mathrm{ha}^{-1}\right)$ & 209.10 & 208.00 \\
\hline
\end{tabular}


Table 2. Treatment used in rice (a basal dose of $30 \mathrm{~kg} \cdot \mathrm{N} \cdot \mathrm{ha}^{-1}$ was applied to all the treatments).

\begin{tabular}{|c|c|c|c|c|c|c|}
\hline \multirow{2}{*}{$\begin{array}{c}\text { Treatment details } \\
\text { Variety } \times \mathrm{N} \text { management }\end{array}$} & \multicolumn{2}{|c|}{$\begin{array}{l}\text { Number of } \\
\text { splits }\end{array}$} & \multicolumn{2}{|c|}{ Total $\mathrm{N}$ applied $\left(\mathrm{kg} \cdot \mathrm{ha}^{-1}\right)$} & \multicolumn{2}{|c|}{ Time of $\mathrm{N}$ application (DAT) } \\
\hline & 2005 & 2006 & 2005 & 2006 & 2005 & 2006 \\
\hline \multicolumn{7}{|l|}{ NDR-359 } \\
\hline Recommended dose of $\mathrm{N}$ & 3 & 3 & $30+60+30=120$ & $30+60+30=120$ & $0,31,62$ & $0,31,62$ \\
\hline $20 \mathrm{~kg} \cdot \mathrm{N} \cdot \mathrm{ha}^{-1}$ of $\mathrm{LCC} \leq 2$ & 4 & 3 & $30+20+20+20=90$ & $30+20+20=70$ & 0,31 & $0,31,53$ \\
\hline $20 \mathrm{~kg} \cdot \mathrm{N} \cdot \mathrm{ha}^{-1}$ of $\mathrm{LCC} \leq 3$ & 4 & 3 & $30+20+20+20=90$ & $30+20+20=70$ & $0,25,47,62$ & $0,28,51$ \\
\hline $20 \mathrm{~kg} \cdot \mathrm{N} \cdot \mathrm{ha}^{-1}$ of $\mathrm{LCC} \leq 4$ & 5 & 4 & $30+20+20+20+20=110$ & $30+20+20+20=90$ & $0,18,38,48,61$ & $0,20,41,63$ \\
\hline $20 \mathrm{~kg} \cdot \mathrm{N} \cdot \mathrm{ha}^{-1}$ of $\mathrm{LCC} \leq 5$ & 4 & 4 & $30+20+20+20+20=110$ & $30+20+20+20=90$ & $0,16,30,45,61$ & $0,17,38,60$ \\
\hline \multicolumn{7}{|l|}{ Sarju 52} \\
\hline Recommended dose of $\mathrm{N}$ & 3 & 3 & $30+60+30=120$ & $30+60+30=120$ & $0,30,60$ & $0,30,60$ \\
\hline $20 \mathrm{~kg} \cdot \mathrm{N} \cdot \mathrm{ha}^{-1}$ of $\mathrm{LCC} \leq 2$ & 4 & 3 & $30+20+20+20=90$ & $30+20+20=70$ & $0,30,45,58$ & $0,30,52$ \\
\hline $20 \mathrm{~kg} \cdot \mathrm{N} \cdot \mathrm{ha}^{-1}$ of $\mathrm{LCC} \leq 3$ & 4 & 3 & $30+20+20+20=90$ & $30+20+20=70$ & $0,25,44,55$ & $0,29,50$ \\
\hline $20 \mathrm{~kg} \cdot \mathrm{N} \cdot \mathrm{ha}^{-1}$ of $\mathrm{LCC} \leq 4$ & 5 & 4 & $30+20+20+20+20=110$ & $30+20+20+20=90$ & $0,18,35,47,61$ & $0,20,42,62$ \\
\hline $20 \mathrm{~kg} \cdot \mathrm{N} \cdot \mathrm{ha}^{-1}$ of $\mathrm{LCC} \leq 5$ & 5 & 4 & $30+20+20+20+20=110$ & $30+20+20+20=90$ & $0,17,35,43,60$ & $0,18,39,60$ \\
\hline \multicolumn{7}{|l|}{ HUBR 2-1 } \\
\hline Recommended dose of $\mathrm{N}$ & 3 & 3 & $30+60+30=120$ & $30+60+30=120$ & $0,30,60$ & $0,30,60$ \\
\hline $20 \mathrm{~kg} \cdot \mathrm{N} \cdot \mathrm{ha}^{-1}$ of $\mathrm{LCC} \leq 2$ & 4 & 3 & $30+20+20+20=90$ & $30+20+20=70$ & $0,30,43,58$ & $0,31,52$ \\
\hline $20 \mathrm{~kg} \cdot \mathrm{N} \cdot \mathrm{ha}^{-1}$ of $\mathrm{LCC} \leq 3$ & 4 & 3 & $30+20+20+20=90$ & $30+20+20=70$ & $0,27,40,56$ & $0,29,51$ \\
\hline $20 \mathrm{~kg} \cdot \mathrm{N} \cdot \mathrm{ha}^{-1}$ of $\mathrm{LCC} \leq 4$ & 5 & 4 & $30+20+20+20+20=110$ & $30+20+20+20=90$ & $0,18,35,47,62$ & $0,20,40,60$ \\
\hline $20 \mathrm{~kg} \cdot \mathrm{N} \cdot \mathrm{ha}^{-1}$ of $\mathrm{LCC} \leq 5$ & 6 & 5 & $30+20+20+20+20+20=130$ & $30+20+20+20+20=110$ & $0,14,27,40,50,61$ & $0,19,36,49,61$ \\
\hline
\end{tabular}

meter is a convenient and reliable tool for in situ chlorophyll measurement of plant $[17,18]$ and has been used for different crops including rice [8]. Leaf area was calculated in situ by measuring the leaf blade length (1) and width (w) at three stages by the following formula [19].

$$
\text { Leaf area }=\mathrm{k} \times 1 \times \mathrm{w}
$$

with $\mathrm{k}$ being the "adjustment factor", the value of which was 0.75 .

Dry weight of the crop was determined after oven drying it at $65^{\circ} \mathrm{C} \pm$ to constant weight. Further grain and straw samples collected from each plot were dried at $70^{\circ} \mathrm{C}$ in an oven and grounded in the iron grinder. These samples were digested in sulfuric acid $\left(\mathrm{H}_{2} \mathrm{SO}_{4}\right)$ and analyzed for their total $\mathrm{N}$ content by the Kjeldahl method [20].

Efficiency studies of nitrogen were made as per the following formula given by [21]. In the recovery efficiency studies since the nutrient contained in the harvested portion of the crop (only the above ground portion) was considered it was termed as nutrient removed instead of nutrient uptake [22].

Agronomic efficiency (increase in grain yield in $\mathrm{kg} / \mathrm{kg}$ $\mathrm{N}$ applied through LCC)

$$
\mathrm{AE}_{\mathrm{n}}=\frac{\text { Grain yield in LCC N fertilized plit - grain yield in recommended N fertilized plot }}{\text { Quantily of } \mathrm{N} \text { fertilizer applied in LCC N fertilized plot }}
$$

\section{Recovery efficiency $\mathrm{RE}_{\mathrm{n}}(\%)$}

$\mathrm{RE}_{\mathrm{n}}=$

Total $\mathrm{N}$ removed $(\mathrm{kg} / \mathrm{ha})$ in LCC $\mathrm{N}$ fertilized plot - Total $\mathrm{N}$ removed $(\mathrm{kg} / \mathrm{ha})$ in recommended $\mathrm{N}$ fertilized plot $\times 100$

Quantily of $\mathrm{N}$ fertilizer applied in LCC N fertilized plot

Analyses of the data were done as per the methodology of Gomez and Gomez [23]. Functional relationships between LCC score and chlorophyll content (SPAD) were worked out using MS Excel (2003) and the accepted significance level was 0.05 .

\section{Results and Discussion}

For all the three varieties total nitrogen applied with LCC $\leq 2$ and $\leq 3$ were 90 and $70 \mathrm{~kg} / \mathrm{ha}$, while it was 110 and $90 \mathrm{~kg} / \mathrm{ha}$ with $\mathrm{LCC} \leq 4$ and $\leq 5$ in first and second year respectively (Table 2). However, under recommended dose of nitrogen it was $120 \mathrm{~kg} / \mathrm{ha}$ applied in 3 splits. For all the varieties the final split application was completed by 61/62 days after transplanting coinciding with the heading stage. A basal application of $30 \mathrm{~kg} \cdot \mathrm{N} / \mathrm{ha}$ was applied under all the treatments as per prevalent package 
of practices of this area.

Among the varieties NDR 359 produced leaves with maximum area/ hill followed by Sarju 52 and HUBR 2-1 respectively and leaf area of NDR 359 was found to be significantly superior to HUBR 2-1 (Table 3). In the leaf colour chart score LCC $\leq 5$ for NDR 359 and Sarju 52 showed significantly higher leaf area than other scores and recommended dose at all the stages of growth. However, in case of HUBR 2-1 LCC $\leq 4$ and $\leq 5$ remained statistically at par with each other with maximum leaf area.

Leaf area index (LAI) was found to increase up to 60 DAT after which it decreased with the passage of time (Table 4). Leaf area index for the varieties and LCC scores were found in the order of NDR $359>$ Sarju $52>$ HUBR 2-1 and LCC $5>4>3>2>$ recommended dose of N. Further, variety was found to interact significantly with LCC score in influencing the LAI. At all the stages of growth the highest LAI was recorded in NDR 359 at $\mathrm{LCC} \leq 5$.

No significant effect in chlorophyll content of leaves due to varieties was observed at any stage of the growth (Table 5). However, significant differences were observed due to LCC scores at all the stages of growth. There was a gradual increase in the chlorophyll content with the increase in LCC score up to $\leq 5$ for NDR 359 and Sarju 52 while for HUBR 2-1 the increase was up to $\leq 4$ only beyond which it declined. Significant differences in dry weight of hill were observed due to both the variables at all the stages of growth during both the years (Table 6). Among the varieties NDR 359 registered maximum dry weight followed by Sarju 52 and HUBR 2-1 while in case of LCC scores the highest dry weight was found with score $\leq 5$ for NDR 359 and Sarju 52 and $\leq 4$ for HUBR 2-1. In all the cases the lowest dry weight was found with recommended dose of $\mathrm{N}$ application.

Similar trend was observed in al the reproductive characters of rice also (Tables 7 and 8). Number of panicles/m, panicle length, panicle weight, filled spikelets/ panicle, grain filling percentage, test weight, grain and straw yields were found to be higher with NDR 359 among the varieties and with LCC $\leq 5$ among the LCC scores except in HUBR 2-1 where LCC $\leq 4$ out yielded LCC $\leq 5$. In the nitrogen removal studies it was observed that maximum amount of $\mathrm{N}$ was removed by NDR 359 which was significantly superior to other two varieties during both the years (Table 9). Among the LCC scores while $\mathrm{N}$ removal from soil was highest at $\leq 5$ for both NDR 359 and Sarju 52, it was highest at LCC $\leq 4$ for HUBR 2-1. Further for agronomic and recovery efficiency of $\mathrm{N}$ it was found to be highest at LCC $\leq 5$ for NDR 359 and Sarju 52 but at LCC $\leq 4$ for HUBR 2-1 (Table 10).

Table 3. Effect of treatments on the leaf area $\left(\mathrm{cm}^{2} \cdot \mathrm{hill}^{-1}\right)$ of rice.

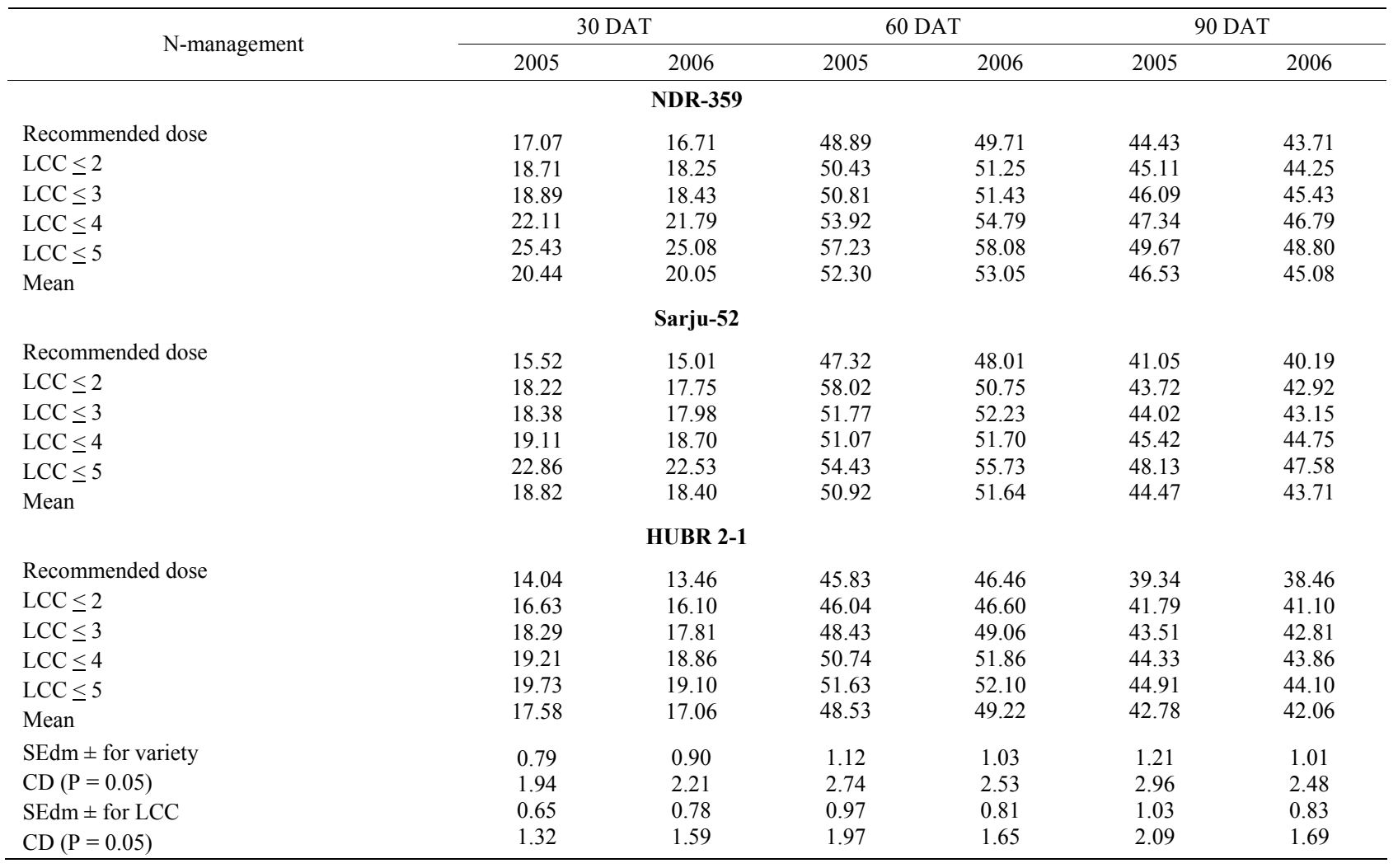


Table 4. Effect of treatments on leaf area index (LAI) of rice.

\begin{tabular}{|c|c|c|c|c|c|c|}
\hline \multirow{2}{*}{ N-management } & \multicolumn{2}{|c|}{$30 \mathrm{DAT}$} & \multicolumn{2}{|c|}{$60 \mathrm{DAT}$} & \multicolumn{2}{|c|}{$90 \mathrm{DAT}$} \\
\hline & 2005 & 2006 & 2005 & 2006 & 2005 & 2006 \\
\hline \multicolumn{7}{|c|}{ NDR-359 } \\
\hline Recommended dose & 1.41 & 1.33 & 4.89 & 4.74 & 4.02 & 3.89 \\
\hline $\mathrm{LCC} \leq 2$ & 1.63 & 1.58 & 5.67 & 5.45 & 4.55 & 4.33 \\
\hline $\mathrm{LCC} \leq 3$ & 1.72 & 1.64 & 5.72 & 5.51 & 4.72 & 4.57 \\
\hline $\mathrm{LCC} \leq 4$ & 1.93 & 1.81 & 6.22 & 6.01 & 4.89 & 4.77 \\
\hline $\mathrm{LCC} \leq 5$ & 2.74 & 2.61 & 7.93 & 7.77 & 6.43 & 6.28 \\
\hline Mean & 1.89 & 1.79 & 6.09 & 5.91 & 4.92 & 4.77 \\
\hline \multicolumn{7}{|c|}{ Sarju-52 } \\
\hline Recommended dose & 1.11 & 1.05 & 4.31 & 4.02 & 3.32 & 3.01 \\
\hline $\mathrm{LCC} \leq 2$ & 1.34 & 1.27 & 4.62 & 4.47 & 3.57 & 3.30 \\
\hline $\mathrm{LCC} \leq 3$ & 1.30 & 1.21 & 5.01 & 4.85 & 3.62 & 3.32 \\
\hline $\mathrm{LCC} \leq 4$ & 1.72 & 1.50 & 5.41 & 5.20 & 3.81 & 3.66 \\
\hline $\mathrm{LCC} \leq 5$ & 2.04 & 1.92 & 6.37 & 6.22 & 4.57 & 4.41 \\
\hline Mean & 1.50 & 1.39 & 5.14 & 4.95 & 3.78 & 3.54 \\
\hline \multicolumn{7}{|c|}{ HUBR 2-1 } \\
\hline Recommended dose & 1.01 & 0.84 & 3.51 & 3.38 & 2.78 & 2.59 \\
\hline $\mathrm{LCC} \leq 2$ & 1.23 & 1.04 & 4.06 & 3.88 & 3.02 & 2.81 \\
\hline $\mathrm{LCC} \leq 3$ & 1.34 & 1.11 & 4.47 & 4.30 & 3.18 & 3.09 \\
\hline $\mathrm{LCC} \leq 4$ & 1.41 & 1.23 & 4.26 & 4.11 & 3.42 & 3.24 \\
\hline $\mathrm{LCC} \leq 5$ & 1.52 & 1.37 & 4.92 & 4.70 & 3.69 & 3.57 \\
\hline Mean & 1.30 & 1.12 & 4.24 & 4.08 & 3.22 & 3.06 \\
\hline $\mathrm{SEdm} \pm$ for variety & 0.10 & 0.06 & 0.28 & 0.22 & 0.15 & 0.09 \\
\hline $\mathrm{CD}(\mathrm{P}=0.05)$ & 0.24 & 0.15 & 0.69 & 0.54 & 0.38 & 0.22 \\
\hline $\mathrm{SEdm} \pm$ for $\mathrm{LCC}$ & 0.09 & 0.07 & 0.21 & 0.20 & 0.20 & 0.14 \\
\hline $\mathrm{CD}(\mathrm{P}=0.05)$ & 0.18 & 0.14 & 0.43 & 0.41 & 0.41 & 0.29 \\
\hline $\mathrm{SEdm} \pm \mathrm{V} \times \mathrm{N}$ & 0.17 & 0.12 & 0.39 & 0.34 & 0.32 & 0.24 \\
\hline $\mathrm{CD}(\mathrm{P}=0.05)$ & 0.35 & 0.24 & 0.79 & 0.69 & 0.65 & 0.49 \\
\hline
\end{tabular}

Table 5. Effect of treatments on chlorophyll content of leaf (SPAD).

\begin{tabular}{|c|c|c|c|c|c|c|}
\hline \multirow{2}{*}{ N-management } & \multicolumn{2}{|c|}{$30 \mathrm{DAT}$} & \multicolumn{2}{|c|}{$60 \mathrm{DAT}$} & \multicolumn{2}{|c|}{$90 \mathrm{DAT}$} \\
\hline & 2005 & 2006 & 2005 & 2006 & 2005 & 2006 \\
\hline \multicolumn{7}{|c|}{ NDR-359 } \\
\hline Recommended dose & 30.90 & 29.95 & 31.67 & 30.70 & 25.87 & 24.90 \\
\hline $\mathrm{LCC} \leq 2$ & 31.61 & 30.60 & 32.29 & 31.35 & 29.78 & 28.85 \\
\hline $\mathrm{LCC} \leq 3$ & 32.46 & 31.65 & 33.45 & 32.40 & 30.01 & 29.08 \\
\hline $\mathrm{LCC} \leq 4$ & 33.43 & 32.40 & 36.06 & 35.15 & 30.66 & 29.75 \\
\hline $\mathrm{LCC}<5$ & 35.56 & 34.68 & 36.38 & 35.43 & 30.68 & 29.71 \\
\hline Mean & 32.79 & 31.85 & 33.97 & 33.00 & 30.20 & 29.46 \\
\hline \multicolumn{7}{|c|}{ Sarju-52 } \\
\hline Recommended dose & 27.68 & 26.65 & 28.35 & 27.40 & 26.22 & 25.28 \\
\hline $\mathrm{LCC} \leq 2$ & 32.01 & 31.18 & 31.69 & 30.75 & 28.78 & 27.88 \\
\hline $\mathrm{LCC} \leq 3$ & 33.66 & 32.75 & 32.85 & 31.93 & 30.97 & 30.08 \\
\hline $\mathrm{LCC} \leq 4$ & 33.97 & 33.00 & 34.61 & 33.50 & 31.81 & 31.00 \\
\hline $\mathrm{LCC} \leq 5$ & 34.68 & 33.75 & 35.45 & 34.50 & 32.86 & 31.93 \\
\hline Mean & 32.40 & 31.46 & 32.59 & 31.61 & 30.13 & 29.23 \\
\hline \multicolumn{7}{|c|}{ HUBR 2-1 } \\
\hline Recommended dose & 27.81 & 26.90 & 31.26 & 30.25 & 22.83 & 23.95 \\
\hline $\mathrm{LCC} \leq 2$ & 28.81 & 27.20 & 31.30 & 30.28 & 28.57 & 27.65 \\
\hline $\mathrm{LCC} \overline{\leq} 3$ & 29.77 & 27.85 & 31.98 & 30.95 & 29.71 & 28.60 \\
\hline $\mathrm{LCC} \leq 4$ & 32.56 & 31.68 & 33.54 & 32.43 & 31.06 & 30.10 \\
\hline $\mathrm{LCC} \leq 5$ & 31.08 & 30.20 & 32.33 & 31.25 & 30.77 & 29.83 \\
\hline Mean & 29.67 & 28.76 & 32.08 & 31.03 & 29.79 & 28.83 \\
\hline $\mathrm{SEdm} \pm$ for variety & 1.46 & 1.54 & 1.56 & 1.62 & 0.62 & 0.70 \\
\hline $\mathrm{CD}(\mathrm{P}=0.05)$ & NS & NS & NS & NS & NS & NS \\
\hline $\mathrm{SEdm} \pm$ for $\mathrm{LCC}$ & 1.01 & 1.20 & 1.08 & 1.16 & 0.54 & 0.65 \\
\hline $\mathrm{CD}(\mathrm{P}=0.05)$ & 2.05 & 2.44 & 2.20 & 2.36 & 1.10 & 1.32 \\
\hline
\end{tabular}


The total leaf area per unit ground area known as LAI increases according to the compound interest law, reaches its maximum value around heading and decreases thereafter with the senescence of lower leaves [24]. LAI being directly correlated to leaf area [19] was found to increase up to $60 \mathrm{DAT}$ along with the growth of the leaf and decreased subsequently due to withering of leaves. It is a well known fact that among the various factors responsible for increase in LAI, tiller number and size of leaves are the most important ones [25] and both these components in turn are greatly influenced by the availability of nitrogen in soil [24]. Higher leaf area and LAI of rice under LCC governed plots in comparison to the fixed time recommended split application of nitrogen clearly indicated that nitrogen availability to rice was much more and assured in the plots where nitrogen was applied as per LCC scores. Further LCC score and chlorophyll content (SPAD) of all the varieties (Table 11) showed a positive correlation (although not significant in all the cases) ranging from $(r=0.631$ to 0.997$)$. Since chlorophyll content depicts the nitrogen status of the plants [2], it indicated that plants under recommended split of nitrogen suffered from nitrogen deficiency at all the stages [10].

The relationship between SPAD values and LCC scores was found to be linear (Figures 1-12) for NDR
359 and Sarju 52, while in HUBR 2-1 it was quadratic at all the stages (Figures 13-18). Overall the SPAD value in case of HUBR 2-1 was found a little less which was most probably due to lesser leaf thickness. Yang et al. [26] also reported from Philippines that leaf thickness directly affected the chlorophyll content and corresponding LCC score in rice. The present results indicated that LCC for real time $\mathrm{N}$ management could not be replaced by SPAD meter for all the rice varieties. Dry matter production is dependent upon the plant's metabolic activities and its corresponding growth. With higher leaf area and chlorophyll content the plant could exhibit higher photosynthetic activities which ultimately led to greater dry matter production. In all the three varieties $\mathrm{N}$ applied through LCC 5 and 4 produced higher plant dry weight. Higher chlorophyll content can lead to higher photosynthetic rate [27] by virtue of higher leaf $\mathrm{N}$ concentration [10], thereby resulting in greater biomass production [28]. Higher efficiency of N applied through LCC was further reflected in the number of filled and unfilled spikelets/ panicle produced by the crop. Significant differences in the filled and unfilled spikelets number between LCC and recommended dose and split of $\mathrm{N}$ application were observed during both the years. Higher leaf area and chlorophyll content under LCC treatment might have led to higher grain filling percentage. Total leaf area coupled

Table 6. Effect of treatments on dry weight of plant $\left(\mathrm{g} \cdot \mathrm{hill}{ }^{-1}\right)$.

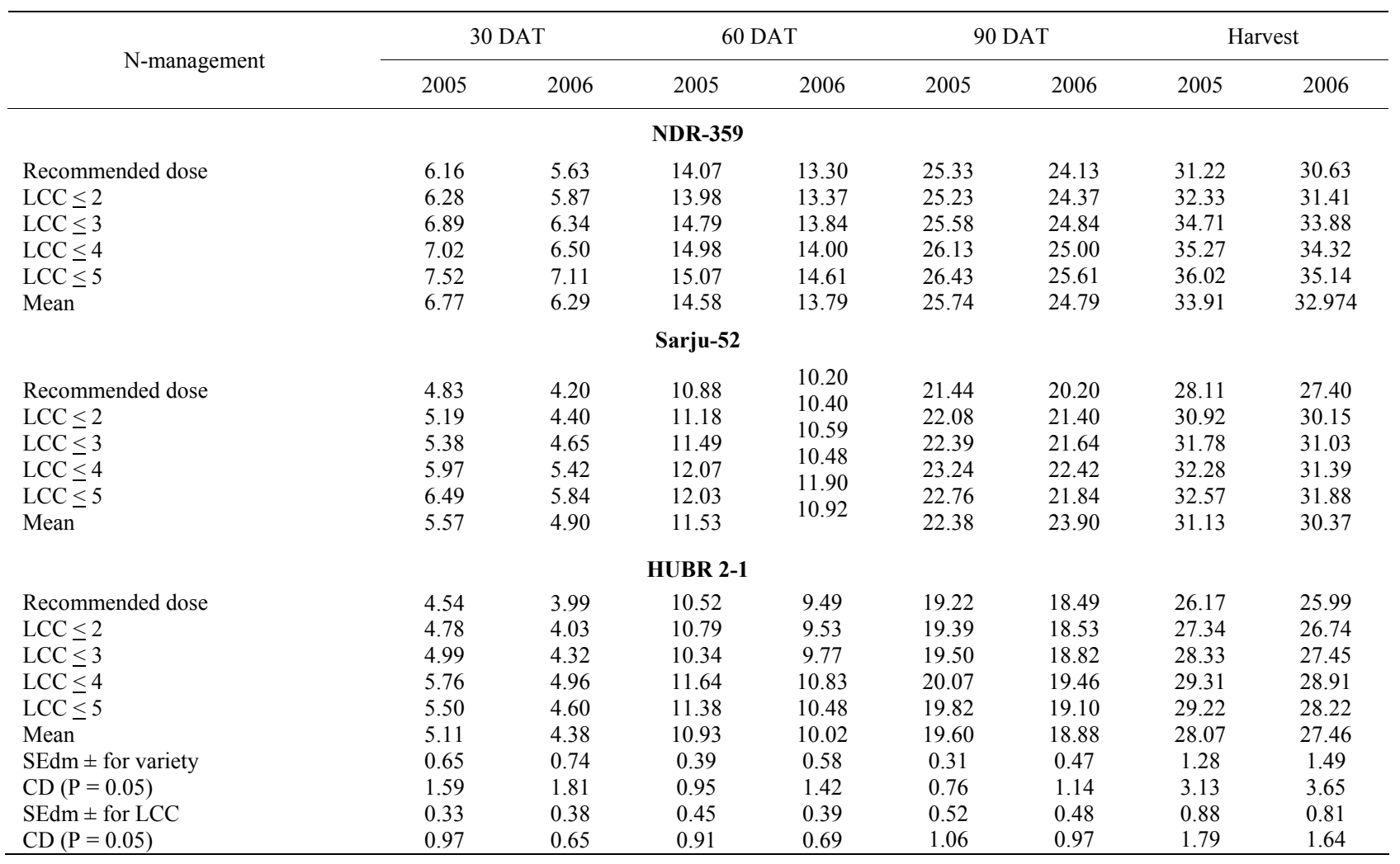


Table 7. Effect of treatments on the yield attributing characters.

\begin{tabular}{|c|c|c|c|c|c|c|c|c|}
\hline \multirow[b]{2}{*}{ N-management } & \multicolumn{2}{|c|}{ Panicles $/ \mathrm{m}^{2}$} & \multicolumn{2}{|c|}{ Panicle length $(\mathrm{cm})$} & \multicolumn{2}{|c|}{ Panicle wt (g) } & \multicolumn{2}{|c|}{ Test wt (g) } \\
\hline & 2005 & 2006 & 2005 & 2006 & 2005 & 2006 & 2005 & 2006 \\
\hline \multicolumn{9}{|c|}{ NDR-359 } \\
\hline Recommended dose & 256.55 & 254.50 & 25.45 & 24.36 & 3.21 & 3.01 & 22.81 & 20.75 \\
\hline $\mathrm{LCC} \leq 2$ & 268.72 & 265.88 & 27.22 & 26.30 & 3.34 & 3.11 & 26.03 & 24.22 \\
\hline $\mathrm{LCC}<3$ & 274.13 & 271.00 & 27.75 & 26.81 & 3.49 & 3.29 & 26.99 & 25.38 \\
\hline $\mathrm{LCC} \leq 4$ & 278.84 & 275.63 & 27.66 & 26.71 & 3.67 & 3.48 & 28.85 & 27.57 \\
\hline $\mathrm{LCC} \leq 5$ & 283.23 & 279.11 & 27.03 & 26.14 & 3.75 & 3.54 & 29.92 & 28.75 \\
\hline Mean & 272.30 & 269.22 & 27.02 & 26.06 & 3.49 & 3.28 & 26.92 & 25.33 \\
\hline \multicolumn{9}{|c|}{ Sarju-52 } \\
\hline Recommended dose & 250.33 & 247.40 & 22.75 & 21.90 & 2.99 & 2.87 & 21.34 & 19.25 \\
\hline $\mathrm{LCC} \leq 2$ & 251.85 & 248.75 & 25.23 & 24.34 & 3.16 & 3.03 & 24.53 & 22.70 \\
\hline $\mathrm{LCC} \leq 3$ & 264.15 & 261.63 & 25.41 & 24.44 & 3.18 & 3.05 & 25.04 & $\begin{array}{l}23.35 \\
26.55\end{array}$ \\
\hline $\mathrm{LCC} \leq 4$ & 268.78 & 263.63 & 26.31 & 25.44 & 3.51 & 3.38 & 27.62 & 26.55 \\
\hline $\mathrm{LCC} \leq 5$ & 270.33 & 265.25 & 26.52 & 25.55 & 3.59 & 3.44 & 27.89 & 26.55 \\
\hline Mean & 261.09 & 257.33 & 25.24 & 24.39 & 3.29 & 3.15 & 25.28 & 23.40 \\
\hline \multicolumn{9}{|c|}{ HUBR 2-1 } \\
\hline Recommended dose & 240.88 & 237.50 & 22.38 & 21.40 & 1.83 & 1.71 & 19.32 & 17.25 \\
\hline $\mathrm{LCC} \leq 2$ & 249.38 & 246.50 & 24.90 & 23.98 & 2.25 & 2.11 & 21.30 & 19.10 \\
\hline $\mathrm{LCC} \leq 3$ & 256.43 & 251.00 & 25.22 & 24.26 & 2.36 & 2.28 & 22.52 & 20.00 \\
\hline $\mathrm{LCC} \leq 4$ & 265.12 & 259.63 & 26.56 & 25.70 & 2.51 & 2.34 & 24.62 & 22.50 \\
\hline $\mathrm{LCC} \leq 5$ & 263.48 & 258.13 & 26.23 & 25.32 & 2.45 & 2.31 & 24.26 & 22.15 \\
\hline Mean & 255.06 & 250.55 & 24.86 & 24.13 & 2.28 & 2.15 & 22.40 & 20.20 \\
\hline $\mathrm{SEdm} \pm$ for variety & 6.03 & 5.51 & 0.72 & 0.57 & 0.18 & 0.15 & 0.59 & 0.44 \\
\hline $\mathrm{CD}(\mathrm{P}=0.05)$ & 14.76 & 13.48 & 1.76 & 1.40 & 0.44 & 0.37 & 1.44 & 0.84 \\
\hline $\mathrm{SEdm} \pm$ for $\mathrm{LCC}$ & 6.83 & 6.26 & 0.54 & 0.49 & 0.20 & 0.17 & 0.29 & 0.08 \\
\hline $\mathrm{CD}(\mathrm{P}=0.05)$ & 13.89 & 12.73 & 1.10 & 1.00 & 0.41 & 0.35 & 0.59 & 0.16 \\
\hline
\end{tabular}

Table 8. Effect of treatments on the yield and yield attributes.

\begin{tabular}{|c|c|c|c|c|c|c|c|c|c|c|}
\hline \multirow[t]{2}{*}{$\mathrm{N}$-management } & \multicolumn{2}{|c|}{$\begin{array}{c}\text { Filled } \\
\text { spikelets/panicle }\end{array}$} & \multicolumn{2}{|c|}{$\begin{array}{c}\text { Unfilled } \\
\text { spikelets/panicle }\end{array}$} & \multicolumn{2}{|c|}{ Grain yield (q/ha) } & \multicolumn{2}{|c|}{ Straw yield (q/ha) } & \multicolumn{2}{|c|}{ Harvest index (\%) } \\
\hline & 2005 & 2006 & 2005 & 2006 & 2005 & 2006 & 2005 & 2006 & 2005 & 2006 \\
\hline \multicolumn{11}{|c|}{ NDR-359 } \\
\hline Recommended dose & 128.11 & 123.26 & 32.63 & 27.70 & 38.03 & 36.00 & 57.11 & 54.99 & 39.97 & 39.47 \\
\hline $\mathrm{LCC} \leq 2$ & 136.43 & 131.58 & 24.66 & 19.72 & 40.02 & 37.13 & 58.09 & 55.93 & 40.79 & 39.90 \\
\hline $\mathrm{LCC} \leq 3$ & 142.32 & 137.58 & 21.62 & 16.57 & 41.98 & 39.39 & 59.22 & 57.18 & 41.48 & 40.79 \\
\hline $\mathrm{LCC} \leq 4$ & 145.61 & 140.05 & 20.32 & 15.46 & 46.12 & 43.99 & 64.31 & 62.19 & 41.76 & 41.43 \\
\hline $\mathrm{LCC} \leq 5$ & 146.01 & 140.64 & 18.63 & 13.70 & 48.33 & 45.87 & 65.35 & 63.31 & 42.51 & 42.01 \\
\hline Mean & 139.70 & 134.65 & 23.57 & 18.63 & 42.90 & 40.47 & 60.82 & 58.72 & 41.30 & 39.47 \\
\hline \multicolumn{11}{|c|}{ Sarju-52 } \\
\hline Recommended dose & 128.11 & 123.77 & 29.15 & 24.22 & 32.31 & 29.42 & 50.31 & 47.28 & 39.11 & 37.56 \\
\hline $\mathrm{LCC} \leq 2$ & 137.62 & 132.74 & 27.63 & 22.72 & 34.03 & 31.17 & 51.18 & 50.38 & 39.94 & 38.52 \\
\hline $\mathrm{LCC} \leq 3$ & 138.63 & 133.77 & 27.32 & 22.49 & 37.41 & 34.60 & 54.97 & 52.92 & 40.50 & 39.20 \\
\hline $\mathrm{LCC} \leq 4$ & 139.85 & 134.92 & 26.32 & 21.35 & 40.29 & 37.42 & 58.19 & 56.21 & 40.91 & 39.93 \\
\hline $\mathrm{LCC} \leq 5$ & 145.21 & 140.47 & 24.29 & 19.35 & 42.49 & 38.82 & 59.92 & 57.81 & 41.49 & 40.15 \\
\hline Mean & 137.88 & 133.05 & 26.94 & 22.02 & 37.31 & 34.29 & 54.91 & 52.92 & 40.39 & 39.07 \\
\hline \multicolumn{11}{|c|}{ HUBR 2-1 } \\
\hline Recommended dose & 102.39 & 97.75 & 45.19 & 40.50 & 28.29 & 25.38 & 46.21 & 44.18 & 37.97 & 30.47 \\
\hline $\mathrm{LCC} \leq 2$ & 113.49 & 108.62 & 36.11 & 31.04 & 31.33 & 28.48 & 49.25 & 47.28 & 38.88 & 36.55 \\
\hline $\mathrm{LCC} \leq 3$ & 122.09 & 117.17 & 36.97 & 31.02 & 33.01 & 30.08 & 50.72 & 48.88 & 39.42 & 37.305 \\
\hline $\mathrm{LCC} \leq 4$ & 125.37 & 120.00 & 29.17 & 24.25 & 37.29 & 34.78 & 55.32 & 53.58 & 40.27 & 38.68 \\
\hline $\mathrm{LCC} \leq 5$ & 123.61 & 118.55 & 30.39 & 25.48 & 35.51 & 32.43 & 53.17 & 51.23 & 40.04 & 37.56 \\
\hline Mean & 117.39 & 112.41 & 35.41 & 30.45 & 33.09 & 30.23 & 50.93 & 49.03 & 39.32 & 36.06 \\
\hline $\mathrm{SEdm} \pm$ for variety & 4.01 & 3.82 & 2.01 & 2.11 & 0.67 & 0.55 & 0.71 & 0.60 & 0.35 & 0.26 \\
\hline $\mathrm{CD}(\mathrm{P}=0.05)$ & 9.81 & 9.35 & 4.92 & 3.15 & 1.64 & 1.34 & 1.74 & 1.48 & 0.86 & 0.64 \\
\hline $\mathrm{SEdm} \pm$ for $\mathrm{LCC}$ & 3.41 & 3.33 & 1.63 & 1.78 & 0.58 & 0.45 & 0.56 & 0.49 & 0.28 & 0.22 \\
\hline $\mathrm{CD}(\mathrm{P}=0.05)$ & 6.93 & 6.75 & 3.31 & 3.61 & 1.18 & 0.89 & 1.14 & 0.98 & 0.57 & 0.46 \\
\hline
\end{tabular}


Table 9. Effect of treatments on removal of nitrogen.

\begin{tabular}{|c|c|c|c|c|c|c|}
\hline \multirow{2}{*}{ N-management } & \multicolumn{2}{|c|}{$\mathrm{N}$ removed by grain $(\mathrm{kg} / \mathrm{ha})$} & \multicolumn{2}{|c|}{$\mathrm{N}$ removed by straw $(\mathrm{kg} / \mathrm{ha})$} & \multicolumn{2}{|c|}{ Total $\mathrm{N}$ removed $(\mathrm{kg} / \mathrm{ha})$} \\
\hline & 2005 & 2006 & 2005 & 2006 & 2005 & 2006 \\
\hline \multicolumn{7}{|c|}{ NDR-359 } \\
\hline $\mathrm{LCC}<2$ & 47.19 & 45.29 & 33.51 & 31.95 & 80.62 & 77.20 \\
\hline $\mathrm{LCC}<3$ & 48.57 & 47.62 & 35.63 & 33.51 & 84.25 & 81.05 \\
\hline $\mathrm{LCC}<4$ & 55.33 & 54.43 & 40.47 & 39.03 & 95.69 & 93.44 \\
\hline $\mathrm{LCC}<5$ & 59.23 & 58.15 & 44.01 & 41.58 & 103.16 & 99.79 \\
\hline Mean & 49.87 & 48.73 & 36.85 & 34.98 & 86.70 & 83.71 \\
\hline \multicolumn{7}{|c|}{ Sarju-52 } \\
\hline Recommended dose & 36.46 & 35.31 & 27.83 & 25.77 & 64.23 & 60.92 \\
\hline $\begin{array}{ll}\mathrm{LCC}<2 \\
\mathrm{LCC}<3\end{array}$ & 39.11 & 37.75 & 29.01 & 27.86 & 68.17 & 65.71 \\
\hline $\mathrm{LCC}<3$ & 42.56 & 40.43 & 31.16 & 29.99 & 73.62 & 70.37 \\
\hline $\begin{array}{l}\mathrm{LCC}<4 \\
\mathrm{~L} C \mathrm{C}<5\end{array}$ & 47.25 & 44.26 & 35.43 & 33.58 & 82.59 & 77.76 \\
\hline $\mathrm{LCC}<5$ & 51.52 & 50.05 & 39.12 & 36.20 & 90.55 & 86.20 \\
\hline \multicolumn{7}{|c|}{ HUBR 2-1 } \\
\hline Recommended dose & 34.10 & 32.31 & 24.73 & 22.95 & 59.03 & 55.06 \\
\hline $\mathrm{LCC}<2$ & 36.29 & 34.12 & 26.81 & 25.78 & 62.91 & 59.95 \\
\hline $\mathrm{LCC}<3$ & 38.52 & 36.33 & 28.12 & 27.16 & 66.73 & 63.55 \\
\hline $\mathrm{LCC}<4$ & 41.63 & 39.61 & 35.06 & 31.37 & 76.55 & 71.04 \\
\hline $\mathrm{LCC}<5$ & 40.31 & 37.73 & 32.93 & 29.99 & 73.12 & 67.68 \\
\hline Mean & 38.17 & 36.02 & 29.53 & 27.45 & 67.70 & 63.46 \\
\hline $\mathrm{SEdm} \pm$ for varieties & 0.91 & 0.84 & 0.61 & 0.58 & 0.73 & 0.88 \\
\hline $\mathrm{CD}(\mathrm{P}=0.05)$ & 2.23 & 2.06 & 1.49 & 1.22 & 1.79 & 2.15 \\
\hline $\mathrm{SEdm} \pm$ for $\mathrm{LCC}$ & 1.17 & 1.02 & 0.72 & 0.60 & 0.98 & 1.10 \\
\hline $\mathrm{CD}(\mathrm{P}=0.05)$ & 2.38 & 2.07 & 1.46 & 1.22 & 1.99 & 2.24 \\
\hline
\end{tabular}

Table 10. Effect of treatments on grain filling percentage, agronomic and recovery efficiency.

\begin{tabular}{|c|c|c|c|c|c|c|}
\hline \multirow[t]{2}{*}{ N-management } & \multicolumn{2}{|c|}{ Grain filling percentage } & \multicolumn{2}{|c|}{$\begin{array}{l}\text { Agronomic efficiency } \\
\text { (kg grain/kg N applied) }\end{array}$} & \multicolumn{2}{|c|}{ Recovery efficiency of Nitrogen $\left(\mathrm{RE}_{\mathrm{n}}\right)$} \\
\hline & 2005 & 2006 & 2005 & 2006 & 2005 & 2006 \\
\hline \multicolumn{7}{|c|}{ NDR-359 } \\
\hline Recommended dose & 79.70 & 81.60 & - & - & - & - \\
\hline $\mathrm{LCC} \leq 2$ & 84.69 & 86.97 & 2.21 & 1.61 & 12.33 & 14.71 \\
\hline $\mathrm{LCC} \leq 3$ & 86.81 & 89.25 & 4.39 & 4.84 & 16.37 & 20.21 \\
\hline $\mathrm{LCC} \leq 5$ & 88.68 & 91.12 & 9.36 & 10.97 & 30.58 & 36.54 \\
\hline Mean & 85.53 & 87.80 & 5.83 & 6.58 & 20.77 & 25.24 \\
\hline \multicolumn{7}{|c|}{ Sarju 52} \\
\hline Recommended dose & 81.46 & 83.63 & - & - & - & - \\
\hline $\mathrm{LCC} \leq 2$ & 83.28 & 85.39 & 1.91 & 2.50 & 4.38 & 6.84 \\
\hline $\mathrm{LCC} \leq 3$ & 83.54 & 85.61 & 5.67 & 7.40 & 10.43 & 13.50 \\
\hline $\mathrm{LCC} \leq 5$ & 85.67 & 87.89 & 9.26 & 10.44 & 23.93 & 28.09 \\
\hline Mean & & 85.77 & 6.03 & 7.31 & 13.86 & 16.79 \\
\hline \multicolumn{7}{|c|}{ UBR 2-1 } \\
\hline Recommended dose & 69.38 & 70.70 & - & - & - & - \\
\hline $\mathrm{LCC} \leq 2$ & 75.86 & 77.77 & 3.38 & 4.43 & 4.31 & 6.99 \\
\hline $\mathrm{LCC} \leq 3$ & 76.76 & 79.07 & 5.24 & 6.71 & 8.55 & 12.13 \\
\hline $\mathrm{LCC} \leq 4$ & 81.12 & 83.19 & 8.18 & 10.44 & 15.93 & 17.76 \\
\hline $\mathrm{LCC} \leq 5$ & 80.27 & 82.31 & 5.55 & 6.41 & 10.84 & 11.47 \\
\hline Mean & 76.68 & 78.61 & 5.59 & 7.00 & 9.91 & 12.09 \\
\hline $\mathrm{SEdm} \pm$ for variety & - & - & 1.12 & 0.80 & - & - \\
\hline $\mathrm{CD}$ for variety $(\mathrm{P}=0.05)$ & - & - & 2.74 & 1.96 & - & - \\
\hline $\mathrm{SEdm} \pm$ for $\mathrm{LCC}$ & - & - & 1.31 & 0.88 & - & - \\
\hline CD for $\operatorname{LCC}(\mathrm{P}=0.05)$ & - & - & 2.66 & 1.79 & - & - \\
\hline
\end{tabular}


Table 11. Correlation coefficient (r) between chlorophyll content (SPAD) and LCC scores.

\begin{tabular}{|c|c|c|c|c|c|}
\hline \multicolumn{6}{|c|}{ NDR 359} \\
\hline \multicolumn{2}{|c|}{30 DAT } & \multicolumn{2}{|c|}{60 DAT } & \multicolumn{2}{|c|}{ 90DAT } \\
\hline 2005 & 2006 & 2005 & 2006 & 2005 & 2006 \\
\hline $0.973^{*}$ & $0.969^{*}$ & $0.963^{*}$ & $0.958^{*}$ & 0.946 & $0.951^{*}$ \\
\hline \multicolumn{6}{|c|}{ Sarju 52} \\
\hline $0.950^{*}$ & $0.951^{*}$ & $0.992^{* *}$ & $0.997^{* *}$ & $0.975^{*}$ & $0.973^{*}$ \\
\hline \multicolumn{6}{|c|}{ HUBR 2-1 } \\
\hline 0.796 & 0.797 & 0.640 & 0.631 & 0.907 & 0.914 \\
\hline
\end{tabular}

*Significant at $\mathbf{P}=0.05, *$ Significant at $\mathbf{P}=0.01$.

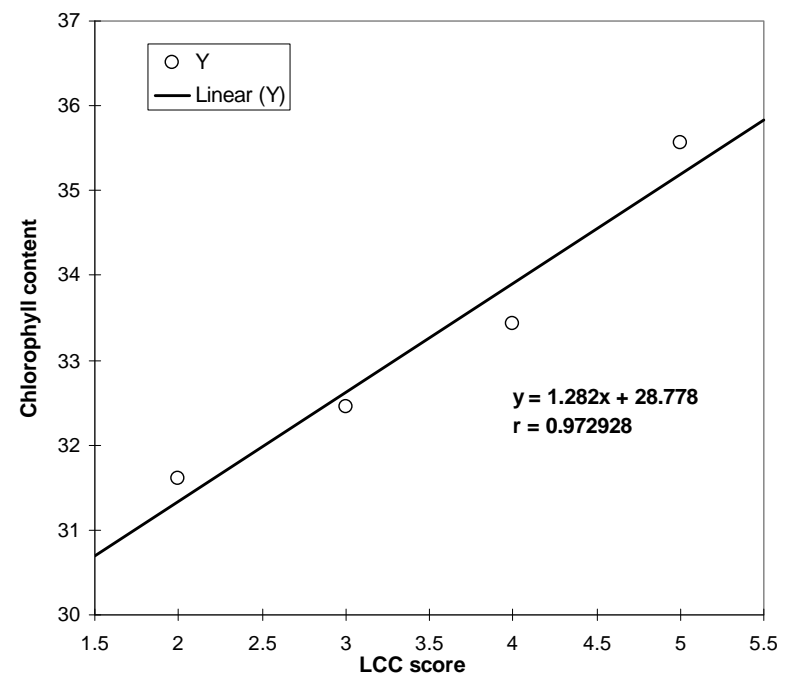

Figure 1. NDR-359, 30 DAT, 2005.

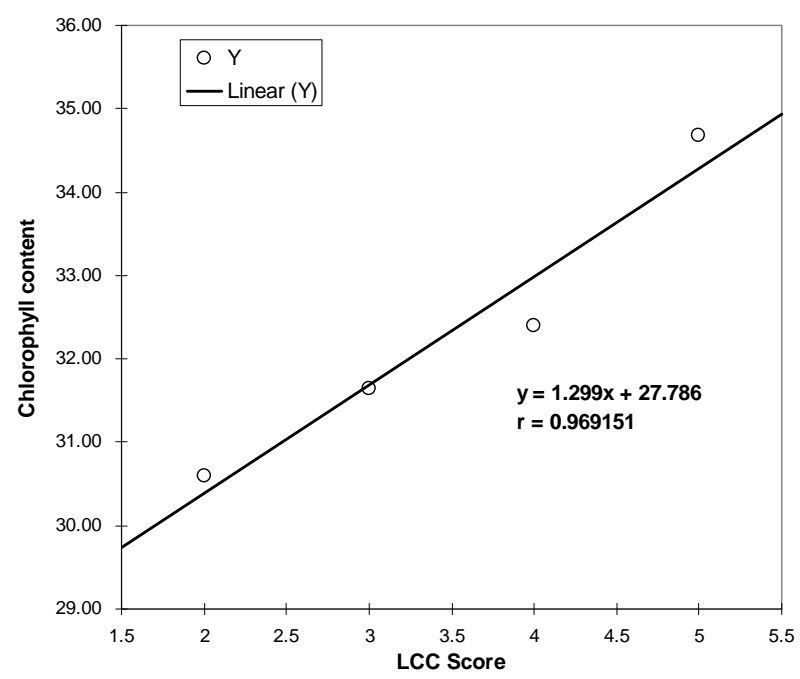

Figure 2. NDR-359, 30 DAT, 2006.

with high chlorophyll content at flowering has been reported to affect the amount of photosynthates available to

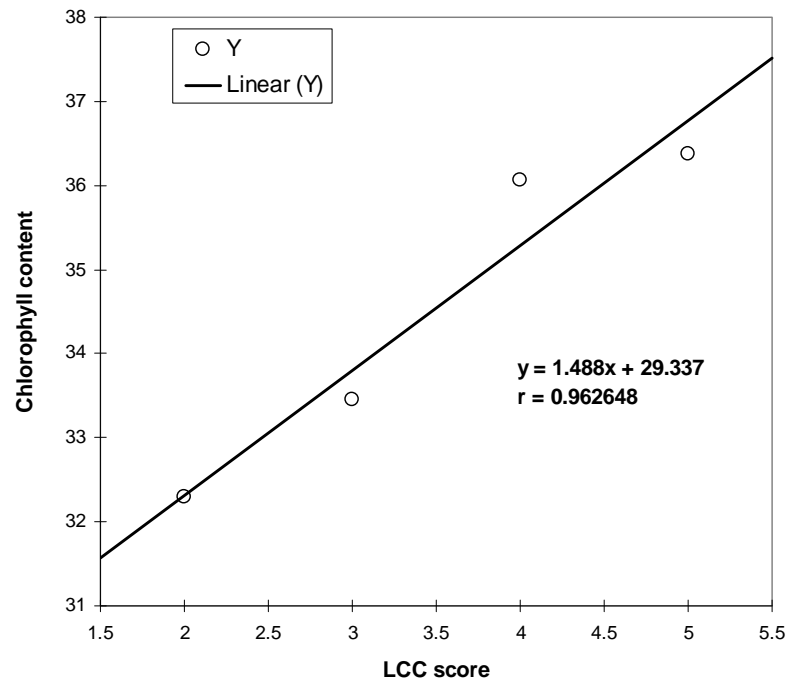

Figure 3. NDR-359, 60 DAT, 2005.

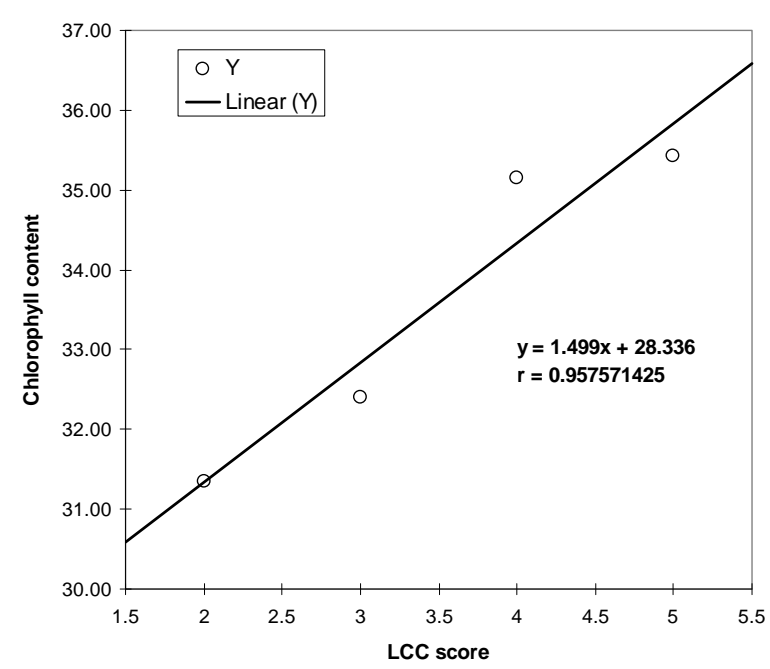

Figure 4. NDR-359, 60 DAT, 2006.

the panicle $[29,30]$.

During both the years of experimentation significant 


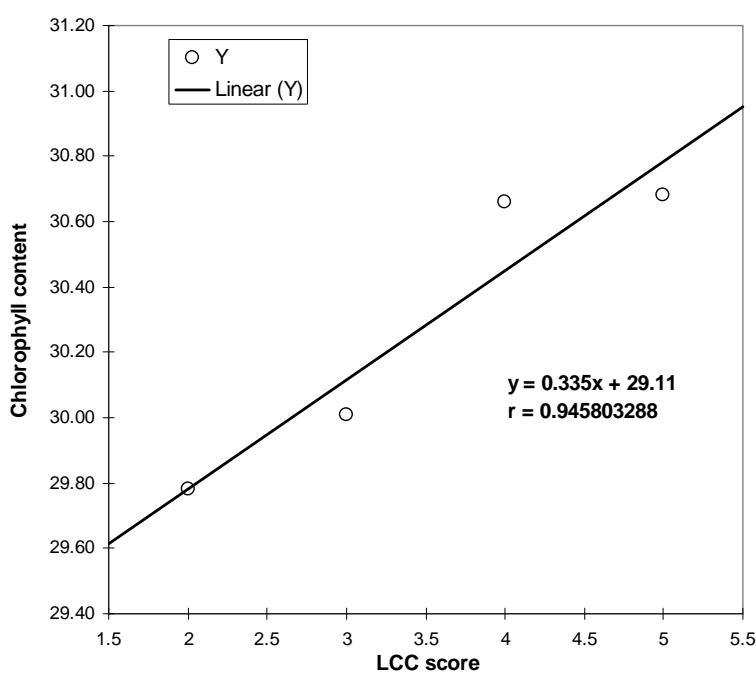

Figure 5. NDR-359, 90 DAT, 2005.

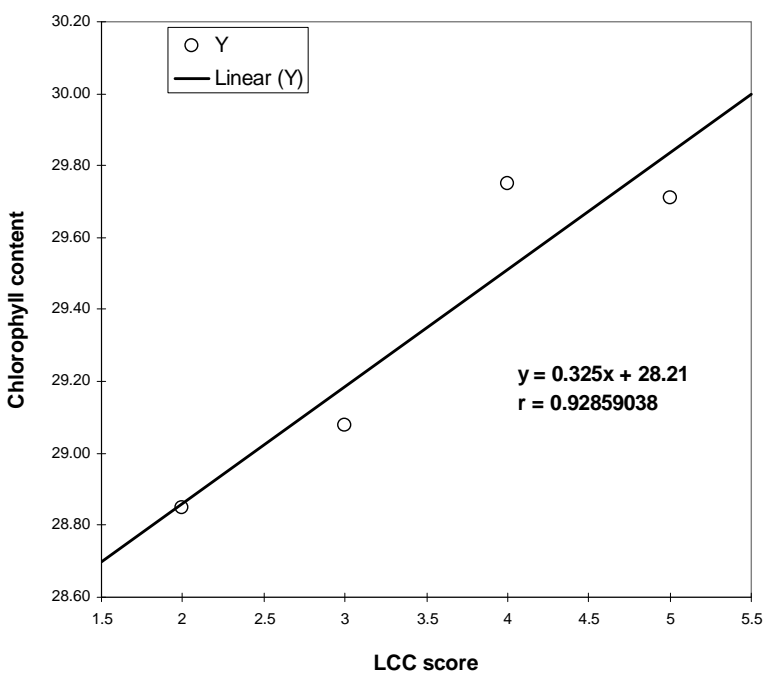

Figure 6. NDR-359, 90DAT, 2006.

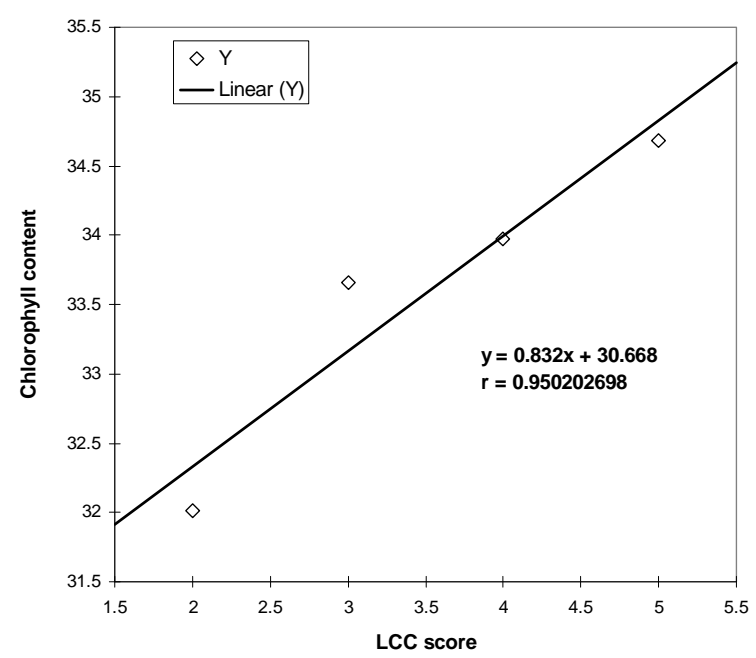

Figure 7. Sarju-52, 30DAT, 2005.

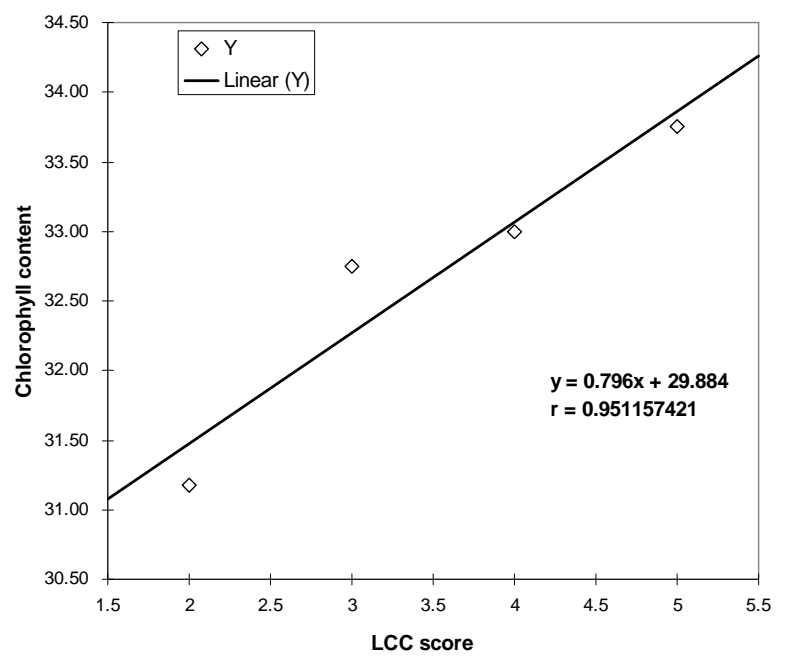

Figure 8. Sarju-52, 30DAT, 2006.

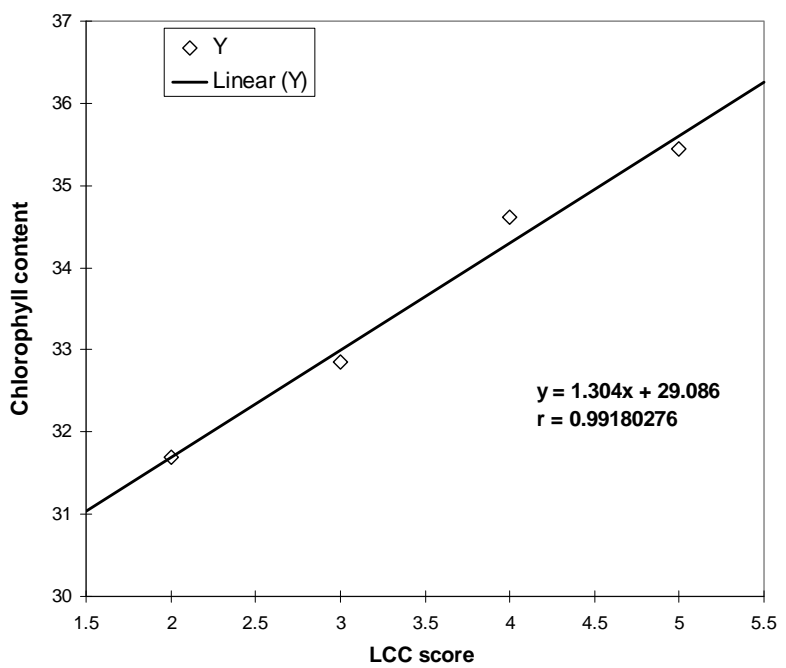

Figure 9. Sarju-52, 60DAT, 2005.

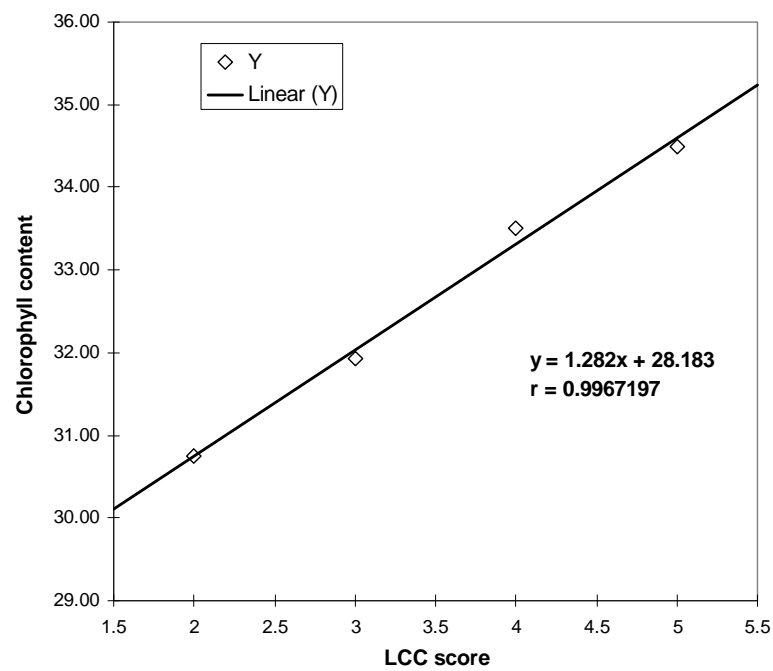

Figure 10. Sarju-52, 60DAT, 2006. 


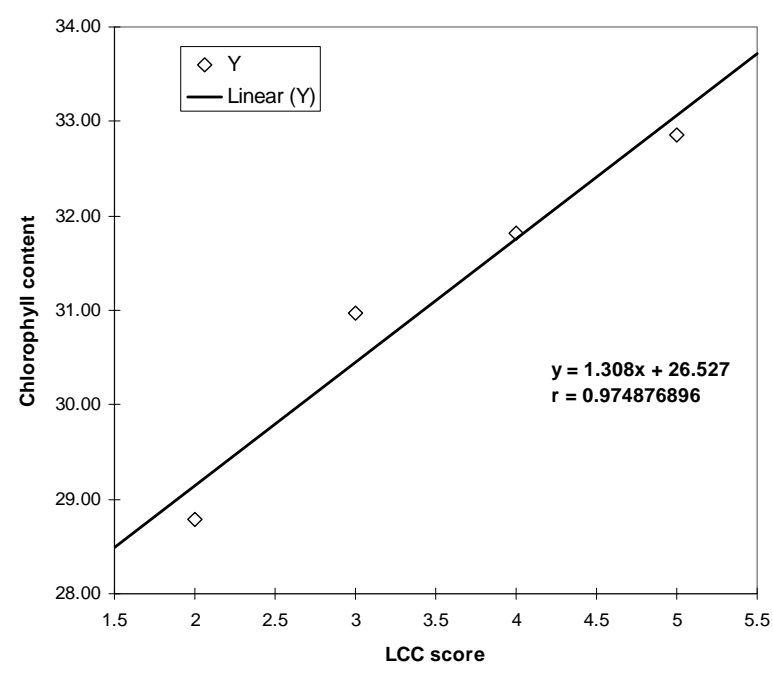

Figure 11. Sarju-52, 90DAT, 2005.

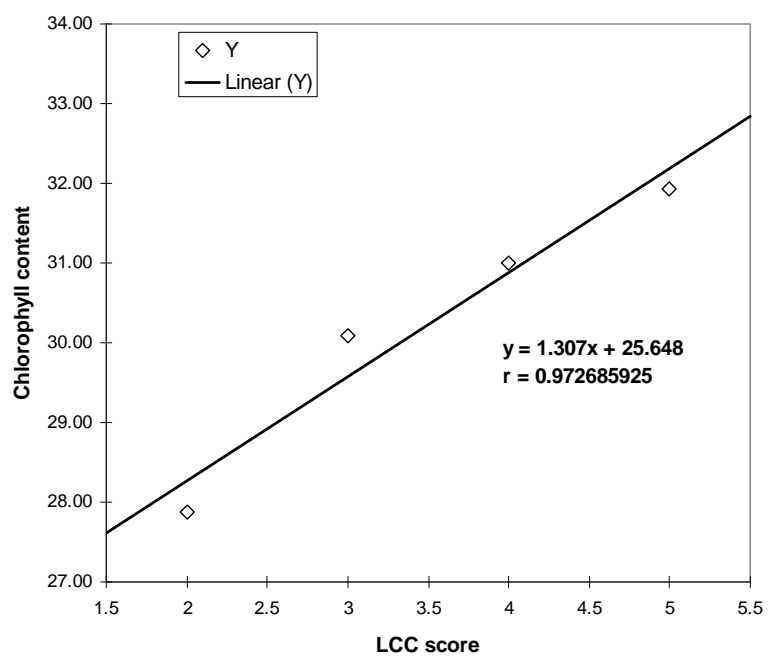

Figure 12. Sarju-52, 90DAT, 2006.

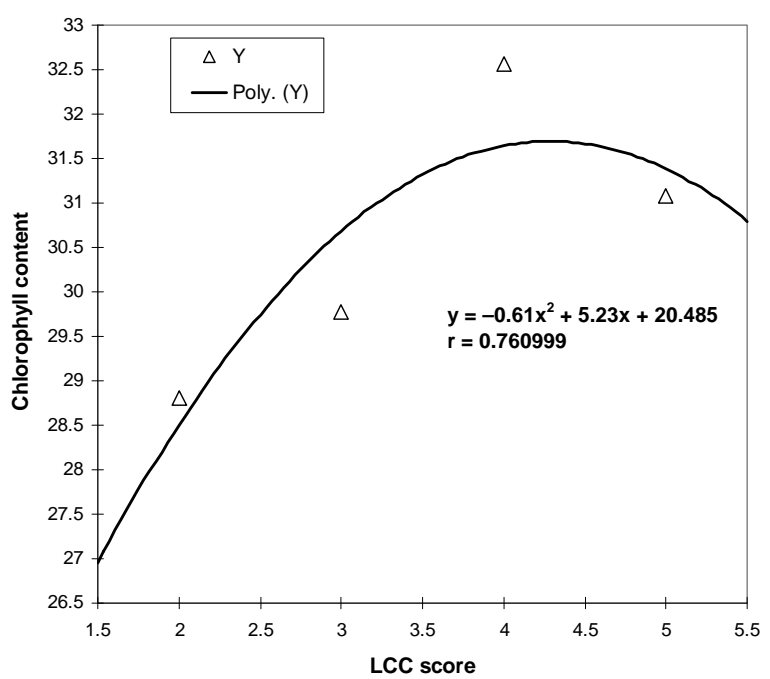

Figure 13. HUBR 2-1, 30DAT, 2005.

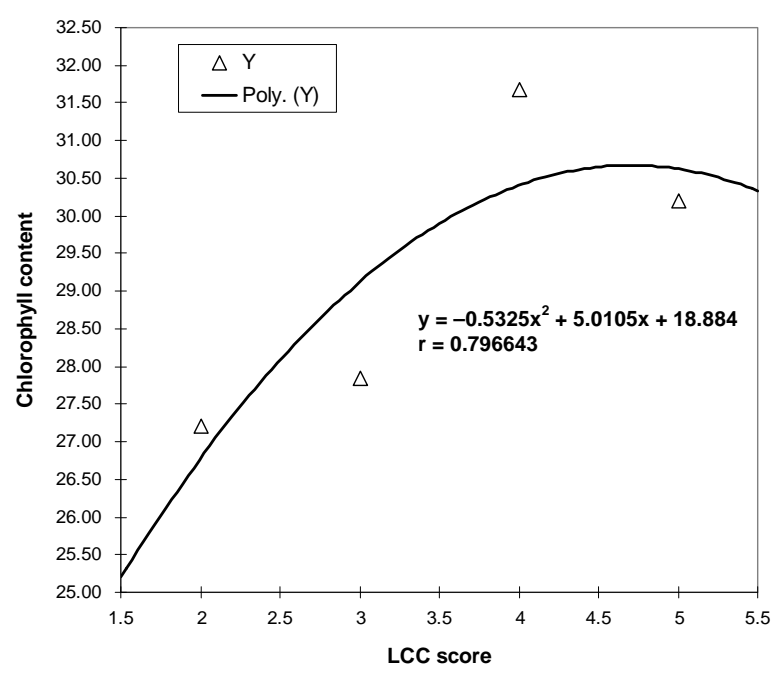

Figure 14. HUBR 2-1, 30DAT, 2006.

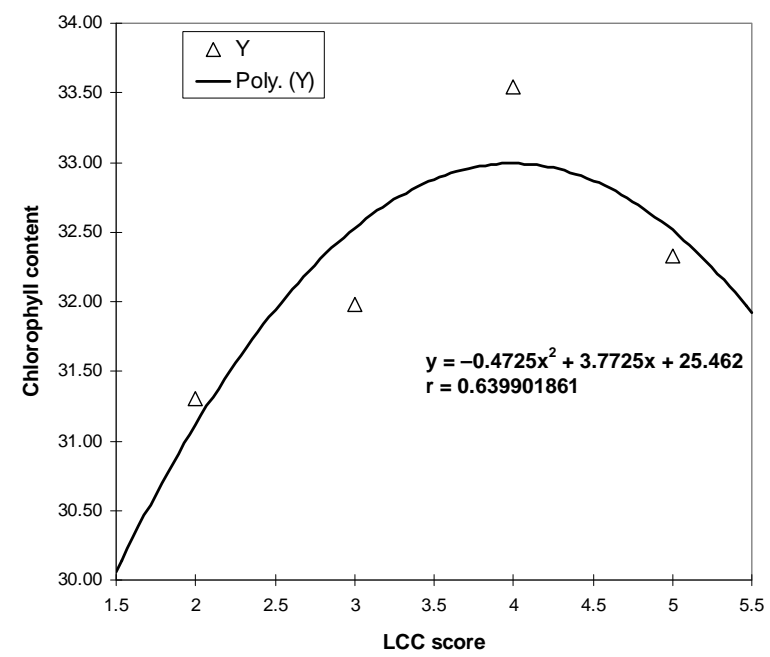

Figure 15. HUBR 2-1, 60DAT, 2005.

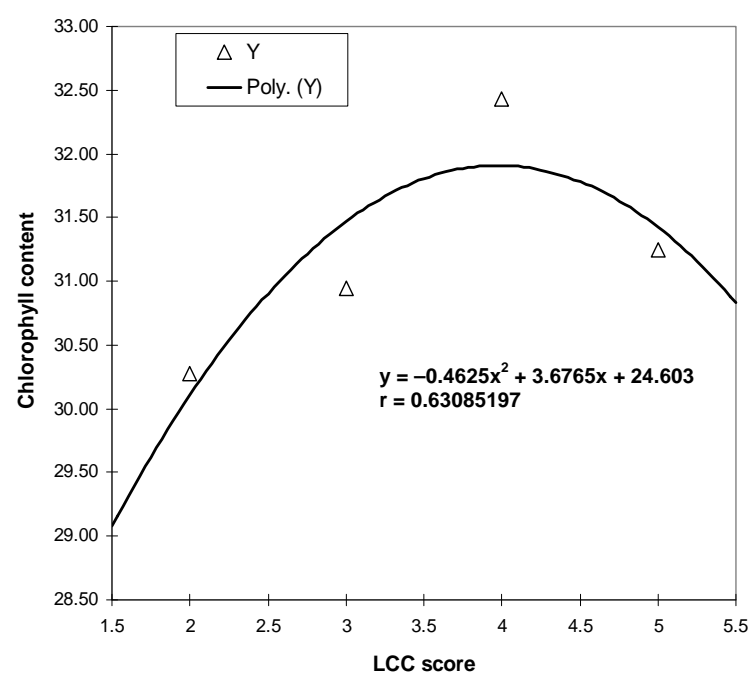

Figure 16. HUBR 2-1, 60DAT, 2006. 


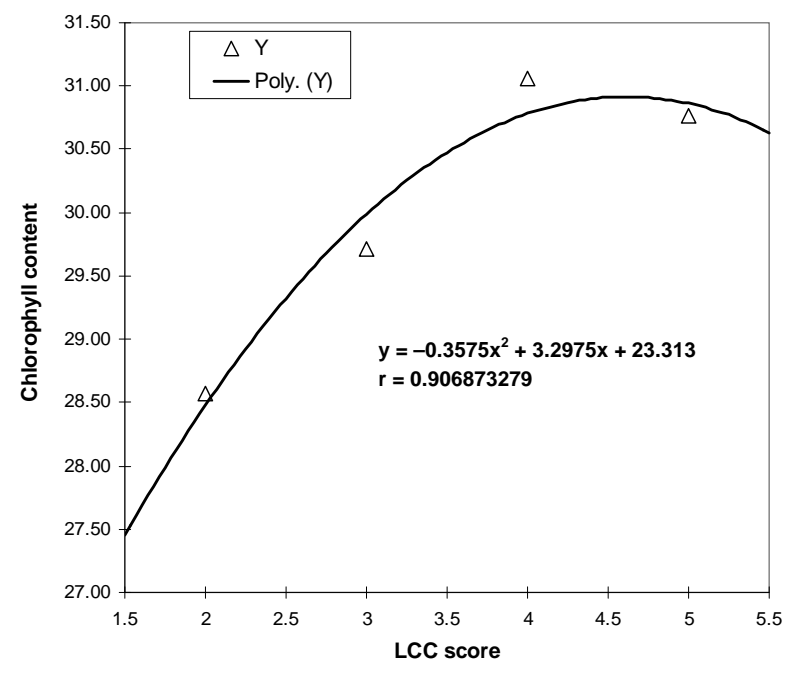

Figure 17. HUBR 2-1, 90DAT, 2005.

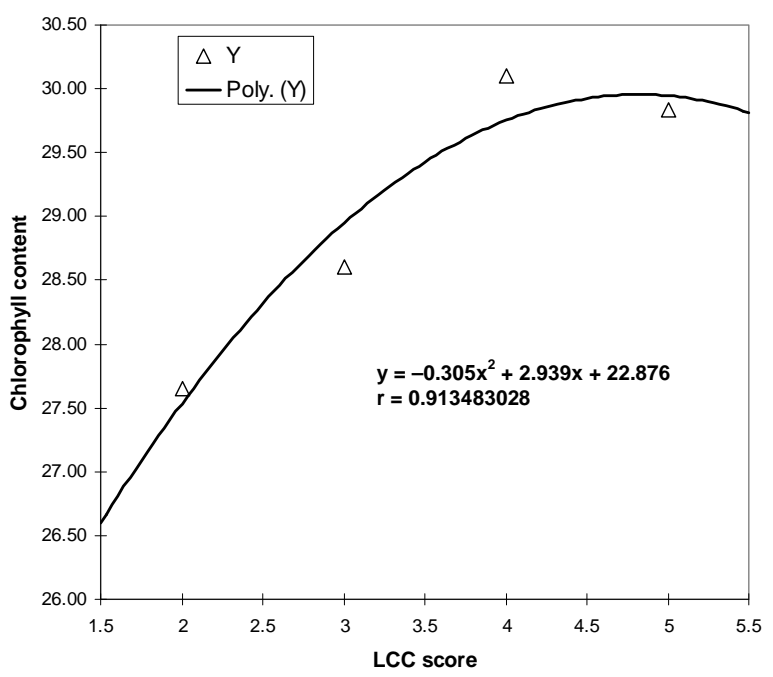

Figure 18. HUBR 2-1, 90DAT, 2006.

differences in grain yield among the varieties were observed. NDR-359 produced maximum yield followed by Sarju 52 and HUBR 2-1 respectively. Among the LCC scores LCC $\leq 5$ produced the highest yield followed by LCC 4, 3 and 2 in NDR-359 and Sarju 52 while in HUBR 2-1 it was $\leq 4$ followed by 5,3 and 2 respectively. In all these cases recommended dose of $\mathrm{N}$ registered the lowest yield although maximum amount of $\mathrm{N}$ i.e. 120 $\mathrm{kg} / \mathrm{ha}$ was applied in this treatment. Corresponding harvest index and $\mathrm{N}$ removal also showed the same trend. Higher harvest index in the LCC-aided N management treatments than the fixed time recommended $\mathrm{N}$ application suggested that fertilizer $\mathrm{N}$ applied on the basis of need of the plant was better translated into grain yield [31]. The threshold value of LCC $\leq 5$ for NDR 359 and Sarju 52 and $\leq 4$ for HUBR 2-1 recorded the highest agronomic and recovery efficiency of nitrogen. In all the three varieties higher threshold value of LCC exhibited higher grain yield per $\mathrm{kg} \mathrm{N}$ applied. Overall, application of $\mathrm{N}$ through LCC could register 15.99 and $15.54 \%$ for NDR 359, 19.33 and $20.68 \%$ for Sarju 52, 21.19 and $23.89 \%$ for HUBR 2-1 higher grain yield than recommended dose and split application of N in 2005 and 2006 respectively.

Nitrogen use efficiency (NUE) is dependent to a large extent on the synchronization between crop nitrogen demand and the available $\mathrm{N}$ supply [31]. Nutrient removal is a function of climate, soil properties, amount and method of fertilizer application and the variety of rice [30] where cultural practices and morphological variations account for differences in nutrient removal. In addition to this dry matter production and yield also govern the nutrient removal. Quite expectedly higher yield by NDR 359 led to higher $\mathrm{N}$ removal which was followed by Sarju 52 and HUBR 2-1 respectively. Similarly under LCC score also total $\mathrm{N}$ removal was found in the sequence of $5>4>3>2>$ for NDR 359 and Sarju 52, while it was $4>5>3>2>$ for HUBR 2-1. In all the cases lowest removal of nitrogen was recorded under the recommended dose and split of $\mathrm{N}$ application. This trend clearly suggested that the loss of $\mathrm{N}$ was maximum under recommended dose of $\mathrm{N}$ application. Yield is correlated to $\mathrm{N}$ requirement and responds positively to solar radiation $[32,33]$ nutrient supply and package of practices [34]. $\mathrm{N}$ management strategy should therefore take into account the crop $\mathrm{N}$ requirement and soil $\mathrm{N}$ supply. LCC strategy calibrated with SPAD determines the real time for efficient management of $\mathrm{N}$ [26]. However, for this critical LCC values are to be determined which may not be same for all the varieties.

\section{Conclusions}

Critical or threshold LCC values are known as those that optimize simultaneously the grain yield and NUE. It has been reported that higher agronomic efficiency of $\mathrm{N}$ with consistent high grain yield could be regarded as an indicator for efficient $\mathrm{N}$ management in rice. On the basis of higher grain yield along with corresponding higher agronomic and recovery efficiency and other parameters LCC $\leq 5$ for NDR 359, Sarju 52 and $\leq 4$ for HUBR 2-1 were judged to be the critical values for proper $\mathrm{N}$ management.

\section{REFERENCES}

[1] S. V.Subbaiah, "Rice Meeting Challenges," The Hindu Survey of Indian Agriculture, 2006, pp. 50-54.

[2] A. K. Shukla, J. K. Ladha, V. K. Singh, B. S. Dwivedi, V. Balasubramanian, R. K. Gupta, S. K. Sharma, S. Yogendra, H. Pathak, P. S. Pandey, A. T. Padre and R. L. Yadav, 
"Calibrating the Leaf Color Chart for Nitrogen Management in Different Genotypes of Rice and Wheat in a Systems Perspective," Agronomy Journal, Vol. 96, No. 6, 2004, pp. 1606-1621. doi:10.2134/agronj2004.1606

[3] T. J. Krupnik, J. Six, J. K. Ladha, M. J. Paine and C. van Kessel, "An Assessment of Fertilizer Nitrogen Recovery Efficiency by Grain Crops," In: A. R. Mosier et al., Eds., Agriculture and the Nitrogen Cycle: Assessing the Impacts of Fertilizer Use on Food Production and the Environment, Scientific Committee on Problems of the Environment (SCOPE), Paris, 2004.

[4] R. L. Yadav, A. T. Padre, P. S. Pandey and S. K. Sharma, "Calibrating the Leaf Color Chart for Nitrogen Management in Different Genotypes of Rice and Wheat in a System,” Agronomy Journal, Vol. 98, 2004, pp. 1606-1621.

[5] K. G. Pillai and D. K. Kundu, "Fertilizer Management in Rice," In: H. L. S. Tandon, Ed., Fertilizer Management in Food Crops, Fertilizer Development and Consultation Organization, New Delhi, 1993, pp. 1-26.

[6] J. K. Ladha, K. S. Fischer, M. Hossain, P. R. Hobbs and B. Hardy, Eds., "Improving the Productivity and Sustainability of Rice-Wheat Systems of the Indo-Gangetic Plains," A Synthesis of NARS-IRRI Partnership Research Discussion Paper 40, IRRI, Los Banos, 2000.

[7] S. Bijay, S. Yadvinder, J. K. Ladha, K. F. Bronson, V. Balasubramanian, S. Jagdeep and C. S. Khind, "Chlorophyll Meter and Leaf Color Chart-Based Nitrogen Management for Rice and Wheat in Northwestern India," Agronomy Journal, Vol. 94, No. 4, 2002, pp. 821-829. doi:10.2134/agronj2002.0821

[8] F. Hussain, K. F. Bronson, S. Yadvinder, S. Bijay and S. Peng, "Use of Well-Fertilized Reference Plots for Chlorophyll-Meter Based Nitrogen Management in Irrigated Rice," Agronomy Journal, Vol. 92, 2000, pp. 875-879.

[9] L. M. Dwyer, M. Tollenaar and L. Houwing, "A NonDestructive Method to Monitor Leaf Greenness in Corn," Canadian Journal of Plant Science, Vol. 71, 1991, pp. 505-509. doi:10.4141/cjps91-070

[10] T. M. Blackmer and J. S. Schepers, "Techniques for Monitoring Crop Nitrogen Status in Corn," Communications in Soil Science and Plant Analysis, Vol. 25, No. 9-10, 1994, pp. 1791-1800. doi:10.1080/00103629409369153

[11] R. H. Follet, R. F. Follet and A. D. Halvorson, "Use of a Chlorophyll Meter to Evaluate the Nitrogen Status of Dryland Winter Wheat," Communications in Soil Science and Plant Analysis, Vol. 23, No. 7-8, 1992, pp. 687-697. doi:10.1080/00103629209368619

[12] M. N. Budhar, "Leaf Colour Chart with Nitrogen Management in Direct Seeded Puddled Rice (Oryza Sativa L)," Fertilizer News, Vol. 50, No. 3, 2005, pp. 41-44.

[13] M. M. Alam, J. K. Ladha, K. S. Rahaman, H. R. Foyjunnessa, A. H. Khan and R. J. Buresh, "Leaf Color Chart for Managing Nitrogen Fertilizer in Lowland Rice in Bangladesh," Agronomy Journal, Vol. 97, No. 3, 2005, pp. 949-959.doi:10.2134/agronj2004.0206
[14] M. M. Alam, M. A. A. Sikder, M. S. Islam, V. Kumar and J. K. Ladha, "Integrated Crop Management: A Potential Agronomic Technique for Increased Productivity and Profit of Rice Cultivation in Bangladesh," $4^{\text {th }}$ World Congress on Conservation Agriculture, Abstracts, New Delhi, 4-7 February 2009, p. 106.

[15] E. M. E. Baksh, O. Erenstein and S. L. G. Page, "Livelihood Improvement through Resource Conserving Technologies in the Lower Gangetic Plains of Northern Bangladesh," $4^{\text {th }}$ World Congress on Conservation Agriculture, Abstracts, New Delhi, 4-7 February 2009, p. 457.

[16] V. Balasubramanian, J. K. Ladha, R. K. Gupta, R. K. Naresh, R. S. Mehla, S. Bijay and S. Yadvinder, "Technology Options for Rice in Rice-Wheat System in South Asia," In: J. K. Ladha, J. E. Hill, J. M. Duxbury, R. K. Gupta and R. J. Buresh, Eds., Improving the Productivity and Sustainability of Rice-Wheat Systems: Issues and Impact, ASA, Special Publication 65, Madison, 2003, pp. 115-147.

[17] S. Peng, F. V. Garcia, R. C. Laza, A. L. Sanico, R. M. Visperas and K. G. Cassman, "Increased Nitrogen Use Efficiency Using a Chlorophyll Meter in High-Yielding Irrigated Rice," Field Crops Research, Vol. 47, No. 2-3, 1996, pp. 243-252. doi:10.1016/0378-4290(96)00018-4

[18] V. Balasubramanian, A. C. Morales, R. T. Cruz and S. Abdulrachman, "On-Farm Adaption of Knowledge Intensive Nitrogen Management Technologies for Rice System," Nutrient Cycling Agroecosystem, Vol. 53, No. 1, 1999, pp. 59-69. doi:10.1023/A:1009744605920

[19] K. A. Gomez, "Techniques for Field Experiments with Rice," International Rice Research Institute, Los Banos, 1972.

[20] J. M. Bremner and C. S. Mulvaney, "Nirogen-Total," In: A. L. Page, et al., Eds., Methods of Soil Analysis, Part 2, 2nd Edition, Agronomy Monograph 9, ASA and SSSA, Madison, 1982. pp. 595-624

[21] K. G. Cassman, S. Peng, D. C. Olk, J. K. Ladha, W. Reichardt, A. Dobermann and U. Singh, "Opportunities for Increased Nitrogen Use Efficiency from Improved Resources Management in Irrigated Lowland Rice Systems," Field Crops Research, Vol. 56, No. 1-2, 1998, pp. 7-38. doi:10.1016/S0378-4290(97)00140-8

[22] R. K. Rattan and N. N. Goswami, "Essential Nutrients and Their Uptake by Plants," In: G. S. Sekhon, P. K. Chhonkar, D. K. Das, N. N. Goswami, G. Narayanasamy, S. R. Poonia, R. K. Rattan and J. L. Sehgal, Eds., Fundamentals of Soil Science, Indian Society of Soil Science, New Delhi, 2002, pp. 309-332.

[23] K. A. Gomez and A. A. Gomez, "Statistical Procedure for Agricultural Research," John Wiley and Sons, New York, 1984, pp. 139-153.

[24] Y. Murata and S. Matsushima, "Rice," In: L. T. Evans, Ed., Crop Physiology, Some Case Histories, Cambridge University Press, London, 1978, pp. 73-99.

[25] A. Tanaka, S. A. Navasero, C. V. Garcia, F. T. Parao and E. Ramirez, "Growth Habit of the Rice Plant in the Tropics and Its Effect on Nitrogen Response," IRRI Technical 
Bulletin, Vol. 3, 1964, pp. 1-80.

[26] W. H. Yang, S. Peng, J. Huang, A. L. Sanico, R. J. Buresh and C. Witt, "Using Leaf Color Charts to Estimate Leaf Nitrogen Status of Rice," Agronomy Journal, Vol. 95, 2003, pp. 212-217.

[27] S. Peng, K. G. Cassman and M. J. Kropff, "Relationship between Leaf Photosynthesis and Nitrogen Content of Field Grown Rice in the Tropics," Crop Science, Vol. 35, No. 6, 1995, pp. 1627-1630. doi:10.2135/cropsci1995.0011183X003500060018x

[28] M. J. Kropff, K. G. Cassman, H. H. van Laar and S. Peng, "Nitrogen and Yield Potential of Irrigated Rice," Plant and Soil, Vol. 155/156, No. 1, 1993, pp. 391-394. doi:10.1007/BF00025065

[29] S. Yoshida and S. B. Ahn, "The Accumulation Process of Carbohydrate in Rice Varieties in Relation to Their Response to Nitrogen in the Tropics," Soil Science and Plant Nutrition (Tokyo), Vol. 14, 1968, pp. 153-161.
[30] S. K. De Datta, "Principles and Practices of Rice Production,” John Wiley \& Sons, New York, 1981, pp. 360-361.

[31] S. Bijay, R. K. Gupta, S. Yadvinder, S. K. Gupta, S. Jagdeep, J. S. Bains and M. Vashishta, "Need-Based Nitrogen Management Using Leaf Color Chart in Wet Direct-Seeded Rice in Northwestern," Indian Journal of New Seeds, Vol. 8, No. 1, 2006, pp. 35-47. doi:10.1300/J153v08n01_03

[32] S. K. De Datta and P. M. Zarate, "Environmental Conditions Affecting Growth Characteristics, Nitrogen Response and Grain Yield of Tropical Rice," Biometeorology, Vol. 4, 1970, pp. 71-89.

[33] International Rice Research Institute, "Climatic Influence on Yield," Annual Report for 1973, IRRI, Los Banos, 1974.

[34] T. Y. Reddy and G. H. S. Reddi, "Principles of Agronomy," 2nd Edition, Kalyani Publishers, Ludhiana, 1995, p. 72. 